\title{
The situation of the Hungarian agricultural higher education
}

\author{
Sándor Magda - Andrea Herneczky - Sándor Marselek - Erika Varga \\ Károly Róbert College, 3200 Gyöngyös, Mátrai u. 36.
}

\begin{abstract}
The knowledge-based, competitive economy places a great emphasis on the education system. The responsibility of higher education is to impart knowledge of high standard which is in harmony with the continuously changing environment. Higher education has a special role in the knowledge-based economy since it does not only have to fulfil educational but also research an innovation tasks.

The decrease in the traditional role of agriculture as well as international tendencies facilitate diversification, i.e. the emergence of new roles and the relevant activities. Due to the diversification of agriculture fields like environmental protection, bioenergetics, and rural development have become more emphatic.

The growing importance of these new fields is also significant from the point of view of education. Well trained professionals are of vital importance for the agriculture.

A significant number of fresh graduates are not employed in their profession; they find a job in other areas or continue their education in a different field of interest.

This research is based on a representative survey amongst agricultural graduates. Its objective is finding facts about how the graduates of the past five years assess higher education training and also about the factors employers take into consideration when employing a fresh graduate.
\end{abstract}

Key words: competitiveness, higher education, employment, mobility

\section{Introduction}

Nowadays knowledge has been given a greater and greater importance. The condition of human resources can decisively determine the economic development of the countries. If we agree that the most important task of education is to train workforce and prepare the people to be integrated in the economy, it is easy to admit that the basis of economic competitiveness is well-qualified labour force. Based on this, knowledge-based society makes such demands on the system of education that can help improve the competitiveness of the economy. The same holds true in respect of agricultural education.

With the scientific and technological development there have been new requirements made regarding knowledge as studying and knowledge itself have become more and more economic factors. From the aspect of the national economy the main function of education is to contribute to the economic growth. This possibility has been highly appreciated to prevent the consequences of the global crisis and triggers a different role of education.

The national and global crisis has had a serious impact on Hungary. To recover the economy, points of breaking out must be defined. We have comparative advantages regarding agricultural production and water supply so they must be made use of when utilising our resources. High standard education as the basis of development can also be accompanied.

\section{Materials and methods}

During our research both primary and secondary sources were applied. Questionnaires were filled in by the former students of agriculture in the past decade which pointed out the utilisation of the gained knowledge, the necessity of practical training, the role of foreign languages, the needs for continuous further trainings and socialisation at work among others. Several hundreds of questionnaires were sent out and their evaluation is in progress now. The primary research included interviews with renowned agricultural specialists e.g. how they saw agricultural higher education and what changes they recommended etc.

The data of the Central Statistical Office and www.felvi.hu are being used for the research to gather all possible information relevant for the topic and to provide the specialists of the future who determine agricultural training with relevant data. The examination focuses on the question how and to what extent the competencies developed by college education can be utilised in the world of labour.

\subsection{Presenting the national higher education}

The appreciation of knowledge in the labour market can also be illustrated by the data below. While $3.2 \%$ of the active population graduated from an institution of higher education in 1960 , this proportion increased to $12.3 \%$ at the time of the change of the regime and was $14.2 \%$ in 2000. In 2006 it reached $16.5 \%$. 
From the beginning of the 1990s integration to higher education was given a greater and greater emphasis in Hungary. The number of students in higher education dramatically rose. This growth was without any interruption till 2004. Since then we can notice a decrease in the number of applicants (Table 1).

Table 1: The number of applicants and those admitted to higher education

\begin{tabular}{|l|c|c|c|c|c|c|}
\hline \multirow{2}{*}{ Year } & \multicolumn{3}{|c|}{ Applicants } & \multicolumn{3}{c|}{ Admitted } \\
\cline { 2 - 7 } & Total & $\begin{array}{c}\text { Under- } \\
\text { graduate } \\
\text { bachelor }\end{array}$ & $\begin{array}{c}\text { Financed } \\
\text { by the } \\
\text { state }\end{array}$ & Total & $\begin{array}{c}\text { Under- } \\
\text { graduate } \\
\text { bachelor }\end{array}$ & $\begin{array}{c}\text { Financed } \\
\text { by the } \\
\text { state }\end{array}$ \\
\hline 2001 & 148880 & 48622 & 50826 & 98031 & 83642 & 106288 \\
\hline 2002 & 164219 & 51148 & 55161 & 108903 & 87405 & 115072 \\
\hline 2003 & 159885 & 50561 & 55108 & 106024 & 84857 & 103163 \\
\hline 2004 & 167082 & 53155 & 59641 & 109562 & 94048 & 115798 \\
\hline 2005 & 149829 & 51195 & 60028 & 102960 & 90601 & 114008 \\
\hline 2006 & 132527 & 52850 & 57796 & 93898 & 83836 & 103422 \\
\hline 2007 & 108854 & 50405 & 48724 & 81563 & 76392 & 88794 \\
\hline 2008 & 96986 & 48567 & 52776 & 81101 & 65240 & 81389 \\
\hline
\end{tabular}

Source: www.felvi.hu

At the 1990s one of the reasons for the dramatic growth was the fact that the generation born at the end of the 1970s reached the age of 18-19. On the other hand, the number of unemployed also increased due to the economic transformation so in the case of applicants to higher education ,procrastinating" entry to the labour market was also a motivating factor.

Analysing the Eurostat data of 2006 we can conclude that the mobility of the Hungarian college and university students significantly lags behind the European average. The problem is not only that a relatively small part of students were given the chance to study abroad for a shorter or a longer time but also the fact that the Hungarian institutions of higher education were not able to provide foreign students with attractive courses -except only some of them. After the change of the regime the growing need for higher education qualification had to be met in many areas so besides working, a lot of people are engaged in different types of trainings (distance education, correspondence etc.).

With the globalisation of the economy knowledge and education are also globalised. Globalisation and information boom created new challenges to higher education (WachtlerMarselek, 2001). The transformation of higher education became indispensable. The creation of such uniformed system ensuring shifts between both majors and institutions was drawn up that helps both student and teacher mobility besides preserving the intellectual achievements and traditions of the single countries so that knowledge piled up in each country could be invested not only within national borders but also beyond them (Magda et al., 2008).

Erasmus programme also helps mobility. At its 1997 launch almost 3 thousand students of the EU took part in it and now 160 thousand students can gain foreign experience every year within its frames. By 2012 the number of participants is expected to grow to 3 million for the full period of the programme. Erasmus supports approximately 25 thousand short term stays abroad for the teachers per year. The programme is also popular in our country and the number of participating students and teachers is on the risealthough not fast enough. To improve this, organisational measures should be taken and steps to make the programme popular are recommended after having studied the present situation carefully.

The tertiary system of education created in the country can make higher education of an acceptable standard possible if the content is good enough. Three objectives are usually separated and addressed in higher education to support competitiveness and create a future as expected in the national development plan:

- the first output (BSc) should serve a competitive labour market,

- the second output (MSc) should be capable of development and scientific training,

- the third output $(\mathrm{PhD})$ should serve the competitive basis for basic sciences, research and development even by international standards (Magda, 2006).

The number of applicants to higher education has gradually been decreasing since 2004 but the ratio of being admitted is getting better. Fewer and fewer students wish to go on studying but the chance of being admitted is significantly improving. In 2004 the ratio of being admitted was only $65.6 \%$ while in $200883.4 \%$ of the applicants were successful.

Regarding more and more important programmes, applications between 2001 and 2008 decreased everywhere. Especially it was agriculture, economic sciences and IT which lost popularity. The trend is shown by Figure 1 .

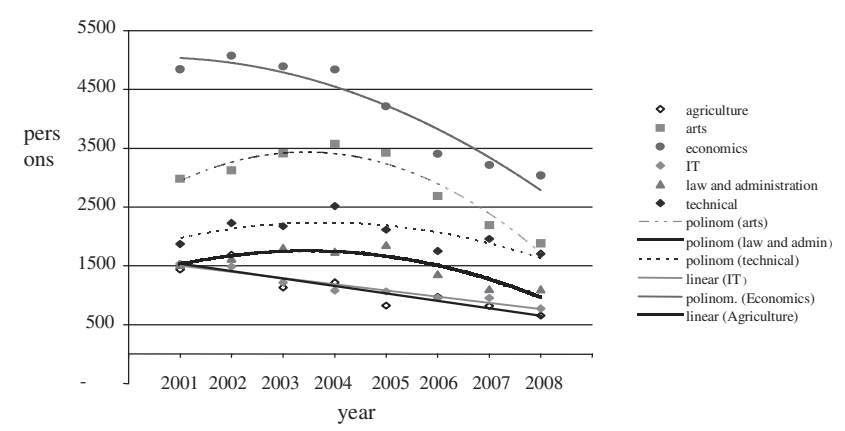

Figure 1: The number of applicants to different important trainings Source: own compilation based on www.felvi.hu

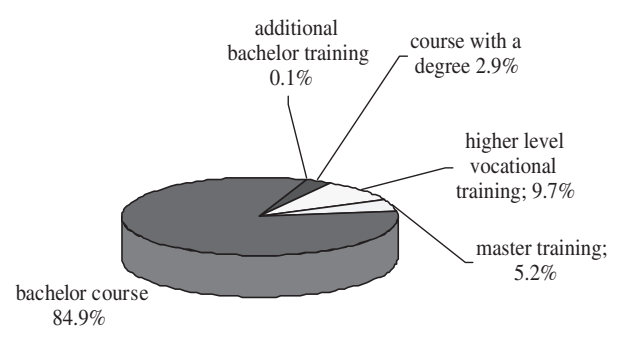

Figure 2: The participation of students admitted to different courses Source: www.felvi.hu 
In $200884.9 \%$ of the students enrolled for a bachelor course and $5.2 \%$ for a master course. The proportion of higher-level vocational training has also increased (Figure 2.)

$69 \%$ of the students admitted wanted to carry on studying in undergraduate, $27.8 \%$ in correspondence, $1 \%$ in evening and $2.2 \%$ in distance education courses in $2008.35 \%$ of them have to pay for their tuition fees while the fees of the remaining $65 \%$ are covered by the state. Knowing a foreign language is not satisfactory in the case of $51.5 \%$ as they do not possess any language certificates.

\subsection{The situation of agricultural education, regional tendencies}

The running of agricultural enterprises requires broad knowledge as without entrepreneurial, market, marketing and technological knowledge no success can be made. According to some data the national agricultural enterprises are less competitive and the employees in Hungarian agriculture are underskilled (Table 2).

Table 2: The division of employees by the highest qualification

\begin{tabular}{|l|c|c|c|c|}
\hline \multirow{2}{*}{ Name } & \multicolumn{2}{|c|}{ Total } & \multicolumn{2}{c|}{ Agricultural } \\
\cline { 2 - 5 } & \multicolumn{3}{|c|}{ Employee } \\
\cline { 2 - 5 } & 1990 & 2005 & 1990 & 2005 \\
\hline $\begin{array}{l}\text { lower than 8 classes } \\
\text { of primary school }\end{array}$ & 5.2 & 0.5 & 11.4 & 2.0 \\
\hline $\begin{array}{l}\text { 8 classes of primary } \\
\text { school }\end{array}$ & 33.4 & 15.1 & 43.9 & 31.4 \\
\hline $\begin{array}{l}\text { secondary school } \\
\text { without GCSE with a } \\
\text { professional certificate }\end{array}$ & 24.4 & 28.9 & 24.8 & 35.4 \\
\hline $\begin{array}{l}\text { secondary school } \\
\text { with a GCSE }\end{array}$ & 24.8 & 34.7 & 14.4 & 22.0 \\
\hline university, college etc. & 12.3 & 20.8 & 5.5 & 9.2 \\
\hline TOTAL & 100.0 & 100.0 & 100.0 & 100.0 \\
\hline
\end{tabular}

Source: Central Statistical Office (hereinafter referred to as CSO), 2008

The Central Statistical office examined the regional differences of agriculture in 2008. In the past seven years hardly any change was made in the agricultural qualification of sole entrepreneurs. The Economic Structural Survey of 2007 showed that the main part (almost 87\%) of the producers conducted their businesses with or without any practical experience. Only $2 \%$ of them had a college or university degree while 6-6\% finished secondary or primary agricultural schools, respectively. Lack of expertise can conserve the past, prevents the implementation of modern, environmentally-friendly and competitive technologies and makes our backlog even greater (Table 3). According to the survey of Székely-Pálinkás (2007) the economic competitiveness of the national agricultural enterprises is questionable.

Underqualification is general and there is no difference between the regions in this respect.

Interest in agricultural education decreased between 2002 and 2007 both in secondary and higher education as well as in andragogy. It is very regrettable as vocational training could be one of the key factors in agricultural development.
Table 3: The composition of sole entrepreneurs by agricultural qualification

\begin{tabular}{|l|c|c|c|c|}
\hline Name & 2000 & 2003 & 2005 & 2007 \\
\hline no experience & 27.9 & 8.5 & 7.8 & 11.2 \\
\hline practical experience $^{\mathrm{a}}$ & $\ldots$ & 79.1 & 79.8 & 75.6 \\
\hline elementary $^{2}$ & 64.8 & 4.8 & 4.9 & 5.7 \\
\hline secondary & 5.9 & 5.5 & 5.6 & 5.6 \\
\hline higher education & 1.9 & 2.1 & 1.8 & 1.8 \\
\hline TOTAL & 100.0 & 100.0 & 100.0 & 100.0 \\
\hline
\end{tabular}

a/ Methodological change; Source: CSO, 2008

174 institutions carried out secondary-level agricultural training in the country in 2007 where altogether 5.9 thousand students studied- three-quarters of them at vocational and special vocational schools while one-quarter at secondary technical schools. Between 2002 and 2007 the total number of students at agricultural special institutions decreased by more than $14 \%$. While the number at vocational schools decreased, the one at secondary technical schools increased.

The number of agricultural students has significantly been decreased in all the regions in the past five years with the exception of Central Hungary where there was an $8 \%$ growth. During this period the southern part of the Great Plains suffered the gravest decrease of over $24 \%$.

The agricultural higher education ensures the supply of specialists in the areas of agriculture, forestry, fishery and animal sciences. Between 2002 and 2007 only 10.5 thousand students were engaged in agricultural higher education, i.e. $3 \%$ of the total number (Table 4 ).

Table 4: The data of students in agricultural special trainings in higher education based on location, 2007

\begin{tabular}{|l|c|c|c|c|}
\hline \multirow{2}{*}{ Region } & persons & $\begin{array}{c}\text { students } \\
\text { breakdown } \\
\%\end{array}$ & $\begin{array}{c}\text { in percen- } \\
\text { tage of } \\
2002\end{array}$ & $\begin{array}{c}\text { persons per } \\
100 \\
\text { thousand } \\
\text { inhabitants }\end{array}$ \\
\hline Central Hungary & 3829 & 36.6 & 95.5 & 132.2 \\
\hline Central Transdanubia & 70 & 0.7 & 37.8 & 6.3 \\
\hline West Transdanubia & 1503 & 14.4 & 92.0 & 150.6 \\
\hline South Transdanubia & 1112 & 10.6 & 158.2 & 115.8 \\
\hline North Hungary & 906 & 8.7 & 84.2 & 73.3 \\
\hline North Great Plains & 1602 & 15.3 & 68.1 & 105.8 \\
\hline South Great Plains & 861 & 8.2 & 32.1 & 64.5 \\
\hline Foreign & 579 & 5.5 & 91.9 & $\mathrm{X}$ \\
\hline TOTAL & 10462 & 100.0 & 78.8 & 104.1 \\
\hline
\end{tabular}

Source: CSO, 2008

To sum it up, interest in the traditional agricultural majors in higher education such as plant production, animal breeding and agricultural engineering has decreased. However, in parallel the majors of food engineering, landscape engineering, economic engineering, environmental management engineering, rural development engineering, mechanical engineering and game management engineering are gaining more and more popularity. The students have a 
vision of the future here and these are the trainings that are less accompanied by heavy, demanding tasks and duties in practice.

Besides the academic vocational training of the young, the training and further training of producers and agricultural managers is also a significant task as their level of qualification is still very low nowadays. The number of those enrolled for agricultural vocational trainings, forestry and fishery has dramatically been fluctuating lately. In 20076.2 thousand students took part in agricultural adult training in the country that comprises hardly $3 \%$ of the 203 thousand participants taking part in non-institutional vocational training.

\subsection{Practical training-illustrated by a French example}

Training in agricultural education at all levels is mainly theoretical. Manual working tasks can only be acquired in practice. The costs of practical training are high so schools cannot cover them. Somogyi (2007) explains that in France there is a kind of educational form that could be transplanted. It is easy to realise if young persons from the countryside went on studying, they were quite likely not to return to the village so in terms of labour force they are lost to the farming communities. If they stayed there, they would not be educated and this would not serve community interests, either. The establishment of the first community centres has its roots in this situation where the families involved undertake the education and practical training of the children of the farming families in the neighbourhood. The activity concentrates on three main ideas till today:

- the personal responsibility for the children

- alternating, rotating form of education, i.e. a given period (usually 1-2 weeks) at a boarding school and the same amount of time in the farm,

- not only a form of education but also socialising and involving students in the life of the community.

This form of education introduces the world of labour starting from the age of 14 , their requirements are acceptable and these young people, who are experts in practice, too, with a degree, could serve as the basis of agricultural higher education after graduation. Such form of training could be organised around famous, traditional schools in the regions depending on the role of agricultural production.

\subsection{The agricultural research}

The National Office for Research and Technology spent more than 15 billion $\mathrm{Ft}$ on research that help increase market and competitiveness as well as modernise production processes in 2004 and 2005. The winning projects could obtain an average of 60-100 million Ft support. In our country there are more than 300 research institutes connected to a part of agriculture (plant production, animal breeding, veterinary, forestry, game management, agricultural technology, agricultural biotechnology etc.).
The total number of full-time employees in R\&D was almost 26000 in 2007 and $12 \%$ of them had a close contact with agriculture as a science. In 2007 of the 246 billion Ft spent on research almost 20 billion was spent on agricultural research, the main part of which was financed by the central budget. In 2007 there were 2400 national research topics nationwide, $40 \%$ of which was carried out in Central Hungary.

The international agricultural research can only amount to $5 \%$ of the total research. The businesses engaged in agriculture possess research institutes to enhance their market effectiveness and competitiveness so in 2007 there were 93 such institutions employing approximately 800 persons.

\section{Preliminary results and discussion}

The preliminary results can be assessed on the basis of the 100 questionnaires returned so some conclusions can also be drawn. The problems of finding a job are huge and $19 \%$ of the job seekers can find a relatively slight number of jobs that are in connection with their profession.

$17 \%$ of the applicants could have been employed in jobs where a degree is not necessary and in the case of $15 \%$ professional practice was missing. Due to the lack of foreign language knowledge $14 \%$ of them could not find a job at all. The opportunities for professional practice and internship during the training period were not regarded favourably by the students: the professionals of the places for internship were not interested in imparting their knowledge and it was only in some cases when students were treated as a colleague in the future. $62 \%$ of them thought "they had been made maximal use of and left alone". $37 \%$ of the students stated to have been working without any professional challenges. Rethinking the professional practice is a very topical question also on the basis of the questionnaire.

$28 \%$ of the graduates regarded a deeper insight into foreign languages, $15-15 \%$ into finance and accountancy as well as legal studies, 13-13\% into economics and marketing important.

\section{Conclusions and recommendations}

Undoubtedly, there is also a need for a shift in attitude in education, as well. The greater proportion of participating agricultural professionals in producing plants is indispensable if we do not want to make our backlog even bigger. A shift to practical training is essential and we can follow the French example above. Most students can only partly use their theoretical knowledge and finding the suitable position is a cause for concern nowadays. According to the survey the most important things are taking teaching foreign languages more seriously as well as updating and broadening knowledge in finance, accountancy, law, economics and marketing. 
Despite the present grave economic situation finding a job was generally successful but not in production rather in the sectors of commerce, services, education or public administration. Counselling activity and training in rural development should be improved as there are significant shortcomings.

The agricultural trainings and further trainings for adults is also a form to be updated in our rapidly changing world.

\section{References}

Castells, M.: A hálózati társadalom kialakulása. Gondolat Infónia Kiadó, 2000.Budapest, pp. 1-662.

Magda, S.: Tudomány és felsőoktatás. Gazdálkodás 2006.50. évf. 6. sz. pp. 68-73.
Magda, S. - Herneczky, A. - Marselek, S.: A felsőoktatás és az agrároktatás dilemmái. Gazdálkodás 2008. 52. évf. 5. sz. pp. 432-444.

Somogyi, N.: Szakképzés - másként Franciaországban. $A z$ Európai Unió Agrárgazdasága, 2007. 12. évf. 4. sz. pp.16-18.

Székely, Cs. - Pálinkás, P.: A hazai mezőgazdasági vállalkozások menedzsmentje európai összehasonlításban. Gazdálkodás 2007. 51. évf. 6. sz. pp. 3-16.

Végh, Z. (szerk.): A mezőgazdaság fejlettségének regionális különbségei. KSH, Szeged, 2008. pp. 1-203.

Wachtler, I. - Marselek, S.(2001): A gazdasági mérnöki szak minőségpolitikájának feladatai a SZIE GMFK oktatásában. Minőségoktatók. VI. Országos Konferenciája, Budapest, 2001. pp. 38-40.

www.felvi.hu 
